\title{
List of tables and boxes
}

\section{Tables}

2.1 Party control of the House and Senate since 1945

2.2 Party identification 3-point scale 1952-98 23

$2.3 a$ The coat-tails effect?

$2.3 b$ Mid-term election performance of the President's party

7.1 Presidential vetoes

\section{Boxes}

1.1 John Locke and the social contract 5

2.1 Jon Corzine v. Bob Franks, New Jersey Senate 2000

3.1 Previous occupations of members of the 106th Congress

4.1 Congressional committees

4.2 Classification of committees

4.3 The battle for campaign finance

5.1 Party leadership in the 107th Congress

6.1 An example of a rule 